\title{
THE DUNEDIN EARTHQUAKE, 9 APRIL, 1974
}

\section{PART 2: LOCAL EFFECTS}

\author{
D. G. Bishop*
}

\begin{abstract}
The earthquake of 9 April, 1974 was the strongest experienced in the Dunedin area in historic times. It was centred at sea about $10 \mathrm{~km}$ south of the city and had a magnitude of 5.0. The felt intensity reached MMVII in the St. Clair area, where a ground acceleration of $0.27 \mathrm{~g}$ was recorded.
\end{abstract}

Variations in felt intensity were determined from a survey of grocery stores. The intensity decreased rapidly away from a maximum on the alluvial ground of the southern suburbs and correlated strongly with the underlying rock type.

The number of claims received by the Earthquake and War Damage Commission was extraordinarily large for an earthquake of this magnitude. Damage, generally of a rather minor nature, was reported from all parts of the city, but was greatly concentrated in the South Dunedin - St. Clair area. About half of the 3000 claims received included chimney damage.

The effects of the earthquake highlight the need to assess the safety of public buildings in Dunedin, particularly those sited on areas of thick alluvium.

\section{INTRODUCTION}

A sharp earthquake was felt throughout the Dunedin City area at $7.50 \mathrm{p} . \mathrm{m}$. on Tuesday, 9 April, 1974. The earthquake had a shallow focus (probably about $20 \mathrm{~km}$ ) about $10 \mathrm{~km}$ south of the city; its magnitude was 5.0 (see Part 1 for details). The main shock was felt as a double event, with an initial tremor followed a second or two later by the main shock. The two events may correspond to the arrival of the $P$ and $S$ waves respectively. After-shocks were felt at $8.20 \mathrm{p.m}$. and $9.50 \mathrm{p.m}$. The main shock was accompanied (many reports state preceded) by a loud roaring noise, and caused considerable public alarm with telephone circuits being jammed and widespread damage occurring to masonry, particularly chimneys, in the St. Clair, st. Kilda and Caversham areas. Power supplies to Corstorphine were interrupted for 45 minutes when high tension switches in the foreshore sub-station were tripped, and all available fire appliances were called out to false alarms caused by the triggering of automatic warning systems. Following the earthquake some 3000 claims totalling about $\$ 250,000$ were received by the Earthquake and Warm Damage Commission, making this earthquake second only to the 1968 Inangahua earthquake as the most damaging in the Commission's records.

Almost all observers reported a strong vertical motion. Swaying of hanging objects was not noticed except in a few peripheral areas, such as near Milton. The earthquake had a felt intensity of MMVI on the Modified Mercalli Scale in the

* N.z. Geological Survey, Department of Scientific and Industrial Research, Box 5342, Dunedin. central city area and an intensity of MMVII at St. Clair.

\section{GEOLOGY}

Dunedin City is built on the southern flank of the Dunedin Volcanic Complex (late Miocene), a series of basaltic lava flows and associated rocks which overlie a succession of lower Tertiary marine sedimentary rocks. Only the uppermost sedimentary unit, the Caversham Sandstone (Oligocene), a thick (c. $230 \mathrm{~m}$ ), creamy white, calcareous sandstone, outcrops within the urban area. The older sedimentary rocks outcrop a few kilometres to the west, where they unconformably overlie the Otago Schist.

Younger alluvial deposits occur mainly around the head of the harbour, especially in the south, where a tombolo has developed to link the volcanic hills of the Peninsula with the mainland.

\section{GEOLOGICAL EFFECTS}

The only fault known to have been active in Recent geological time in the Dunedin region is the Akatore Fault, which has well-preserved Recent fault traces at Taieri Mouth, Big Creek, and Nobles Stream, some $30 \mathrm{~km}$ south-west of Dunedin. As early indications indicated the epicentre might be associated with a submarine north-eastern extension of this fault, the fault traces were inspected but no signs of surface rupture was seen. No instances of landsliding attributable to the earthquake were detected. Foundation subsidence due to compaction did occur beneath a house at St. Clair, however, about two days after the earthquake. 


\section{FELT INTENSITY}

A survey was made of fallen items in 105 small grocery stores throughout the city and as far south at Taieri Mouth and north to Warrington. Such stores have similar stock, stacked in similar fashion and although variations might be expected to arise from differences in building construction, foundation conditions, and types of shelving, it became clear during the course of the survey that variations from such causes were significant only in exceptional and obvious cases, and that the shops were in fact rather satisfactory sites for making comparative observations. The results were initially plotted at a scale of 1: 12,500 and contoured at intervals of $0-5,6-15,16-100$, and more than 100 fallen items. A reduced version of this map is included as Fig. 1.

The siting of the two Dunedin accelerographs allows an approximate calibration of the isoseismals. The Dunedin Central Post office lies just outside the isoseismal marking the consistent appearance of a small number of displaced articles. Here, where the intensity was MMVI, a ground acceleration of $0.12 \mathrm{~g}$ towards the south-west was recorded and hence this value appears to be about the threshold necessary for displacement of cans from stacks or shelves. The St. Clair Telephone Exchange on the other hand lies within the maximum felt intensity contour and here an acceleration of $0.27 \mathrm{~g}$ towards the north-east was recorded.

It is estimated that, in a stronger earthquake, another one or two contours could be drawn on a similar basis provided that interference from structural damage did not occur.

\section{Notable points of this map are:-}

1. The very localised nature of the maximum.

2. The rapid falloff in intensity.

3. The strong correlation between

intensity and lithology.

4. The slight but distinct high along the topographic ridge from Lookout Point, through Mornington, Roslyn and up Taieri Road to Wakari.

The strongest effects were felt on the unconsolidated alluvium of the southern suburbs, with the intensity falling off very steeply on the surrounding consolidated sedimentary and volcanic rocks. The Lookout Point - Wakari high is apparently a topographic effect, which might have been significant in the case of a major earthquake. Comparison of this map with the map of damage claim localities (Fig. 2) suggests that similar but less well defined areas of increased intensity occur on the ridge crests in Brockville, Pinehill and waverley. Unfortunately no shops were available for comparison on the reclaimed land at the eastern end of the harbour, where an even more pronounced response than that on alluvial ground might be expected.

\section{DIRECTION OF MOVEMENT}

Where known, the direction in which items fell was also recorded. As items were restrained in one direction in almost all instances, the direction is plotted as a non-polar azimuth in Fig. 3. A pronounced concentration is found in the north-east - south-west quadrants in harmony with the accelerograph records.

\section{DAMAGE CLAIMS}

The number of claims received (3000) is surprisingly high for an earthquake of this magnitude. The majority of claims were from houses and at least half included chimney damage (see below). Successively less important categories of damage were:cracking of interior plaster, cracking of external masonry, damage to plumbing, breaking of household contents, and damage to tile roofs.

The claim localities were plotted on a street map, initially at a scale of $1: 12500$, and contoured (Fig. 2). Claims were received from all parts of Dunedin and the lowest contour, 20 claims per $\mathrm{km}^{2}$, reflects the limits of the built-up area except in the northern suburbs and Waverley. The maximum contour $(320$ claims per sq $\mathrm{km}$ ) is strongly affected locally by such factors as variations in the number of houses per unit area and by regions of older houses. The north-eastwards extension of the area of maximum claim density (relative to the intensity maximum of Fig. 1) is due to a combination of these factors, as the South Dunedin - st. Kilda area is a high density region of older housing. Such effects could be reduced by expressing the data as the ratio of the number of damage claims to the number of buildings present. This has not been attempted, and the map should therefore be interpreted with some caution. Nevertheless it vividly displays the concentration of damage on the alluvial ground of the southern suburbs, in addition to complementing the felt intensity map.

\section{CHIMNEY DAMAGE}

Two categories of chimney damage were differentiated during an assessment by A. R. Mutch, N.Z. Geological Survey, Dunedin. A zone of light damage (chimney pot displaced, outer plaster dislodged) extended throughout the city and as far afield as Brighton, Port Chalmers and Mosgiel. In a more intense inner zone (Fig. 2) bricks were dislodged and in a few instances a substantial part of the chimney collapsed. In many cases a poor bond between brick and mortar was indicated by the complete disintegration of the fallen section into its component bricks (Fig. 4).

\section{RELATIONSHIP OF INTENSITY TO GEOLOGY}

The effect of the geology is indicated by the departure of the isoseismals from a series of concentric arcs. The most marked effect is the concentrated intensity maximum on the alluvial ground of the southern suburbs, where the western and northern edges of the maximum correspond closely to the edge of the alluvium. The contrast between damage on this area of alluvium and that on the alluvial ground of the northern part of the city is striking. 
Three factors may contribute, in addition to distance from the epicentre.

1. A greater thickness of alluvium in the southern Dunedin area.

2. The composition of the alluvium. The South Dunedin alluvium consists of water-saturated fine sands, silts and muds with interbedded peat and swamp deposits that have accumulated behind the St. Clair - St. Kilda sand spit as it gradually extended westward from the Peninsula, eventually to close off the southern end of Otago Harbour. Meagre records suggests, however, that the North Dunedin alluvium consists largely of bouldery clays.

3. The configuration and possibly the nature of the underlying bedrock.

The intensity maximum is situated along the foot of an old sea cliff and the greatest thickness of alluvium is likely in this area. The thickness of the alluvium is probably the greatest single factor in the accentuated intensity in this region; however, further amplification may have resulted from boundary or focussing effects across the bedrock-alluvium interface. In addition the presence of Caversham Sandstone rather than volcanic rock beneath the western edge of the alluvium may have accentuated the intensity in that area.

The subsidiary maximum on the east side of the South Dunedin alluvium corresponds to a minor basin partly ringed by volcanics and closed to the south by the sand spit. Thicker peat and swamp deposits would be expected in such an environment and may be the reason for this local amplification.

No observations were available from the reclaimed land at the south end of the harbour and no occurrences of subsidence were reported. Subsidence of reclaimed land during earthquakes has been widely documented, however, and such land should be regarded as particularly susceptible foundation material.

The remaining part of the Dunedin urban area is underlain by either volcanic or consolidated Tertiary sedimentary rocks. Both rock groups appear to have had similar responses during the earthquake. Although the weaker isoseismals appear to be extended over the volcanic terrain, this effect may be related to topography and local variations of the stronger isoseismals support the indications from on the spot appraisals that a slightly greater amplification was experienced on the sedimentary rocks.

No information on the behaviour of areas underlain by schist is available.

\section{EARTHQUAKE RISK IN DUNEDIN}

In the last 70 years at least four earthquakes have produced felt intensities of MMV or more in Dunedin, and many more smaller shocks have been felt. The 1974 earthquake, however, is the first to have caused widespread damage. A review of the information available indicates that there is a risk from large distant earthquakes in the South Westland - Fiordland region as well as from smaller, more local shocks.

\section{CONCLUSIONS}

Although the April 1974 earthquake was a relatively small shock, it produced widespread minor damage in Dunedin City. The inordinate amount of damage, however, is more of a sad commentary on the inadequate earthquake resistance of many buildings in Dunedin, than a reflection of the strength of the earthquake.

Variations on felt intensity were determined rapidly and accurately by a survey of displaced items in grocery stores. The felt intensity and amount of damage correlated strongly with the local geology. Assessments of these variations indicate that the greatest response was experienced on deep alluvium (and probably also on reclaimed land) with shallow alluvium, consolidated sedimentary rocks, volcanic rocks and schist being progressively more satisfactory foundation materials. The earthquake was not strong enough to allow an assessment of a slope factor; however, steep slopes, especially where mantled with loose rock and slopewash material would constitute an increased risk factor in a major shock.

The April 1974 earthquake proved conclusively that a significant earthquake risk exists in Dunedin, and showed that many of the older buildings have poor earthquake resistance characteristics. It also served warning of the need for an assessment of the safety of high occupancy public and private buildings such as schools, churches, hospitals, and factories, especially those on the alluvial ground of the southern suburbs.

\section{ACKNOWLEDGEMENTS}

I am grateful to R. T. Hefford, Physics and Engineering Laboratory, for details of the accelerograph records, and I. C. McKellar, K. T. Murray and A. R, Mutch for details of various aspects of the earthquake effects. Constructive comments on the manuscript were provided by R. D. Adams, T. L. Grant-Taylor and G. J. Lensen.

\section{REFERENCES}

Benson, W. N. 1968. Dunedin District 1:50 000. New Zealand Geological Survey Miscellaneous Series Map I. Department of Scientific and Industrial Research, Wellington, New Zealand. 


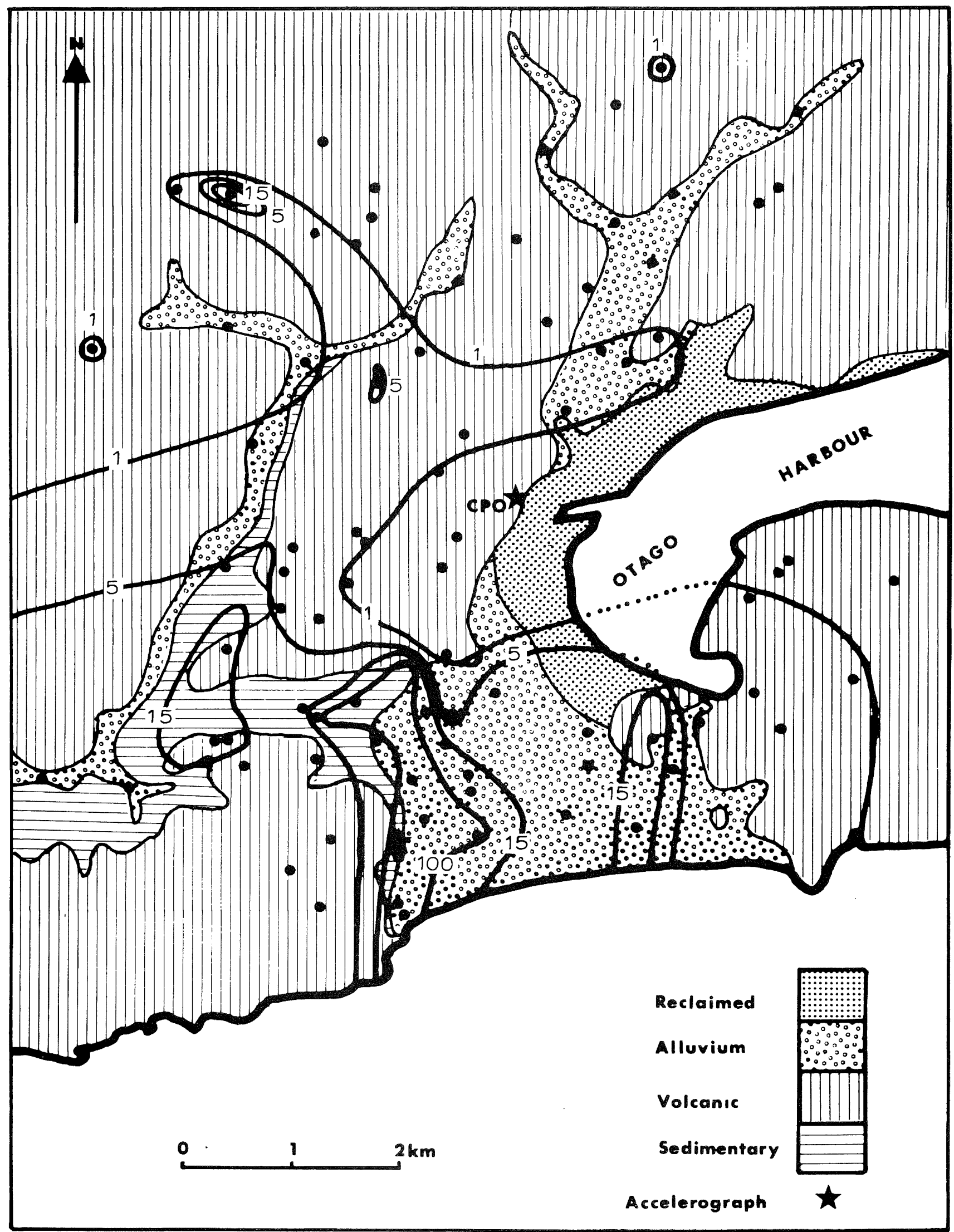

FIGURE 1: SIMPLIFIED GEOLOGICAL MAP OF THE DUNEDIN AREA (AFTER BENSON. 1968) WITH ISOSEISMALS BASED ON THE NUMBER OF FALLEN ITEMS IN GROCERY STORES (HEAVY DOTS). CONTOURS AT 1, 5, 15 AND 100 ITEMS. 


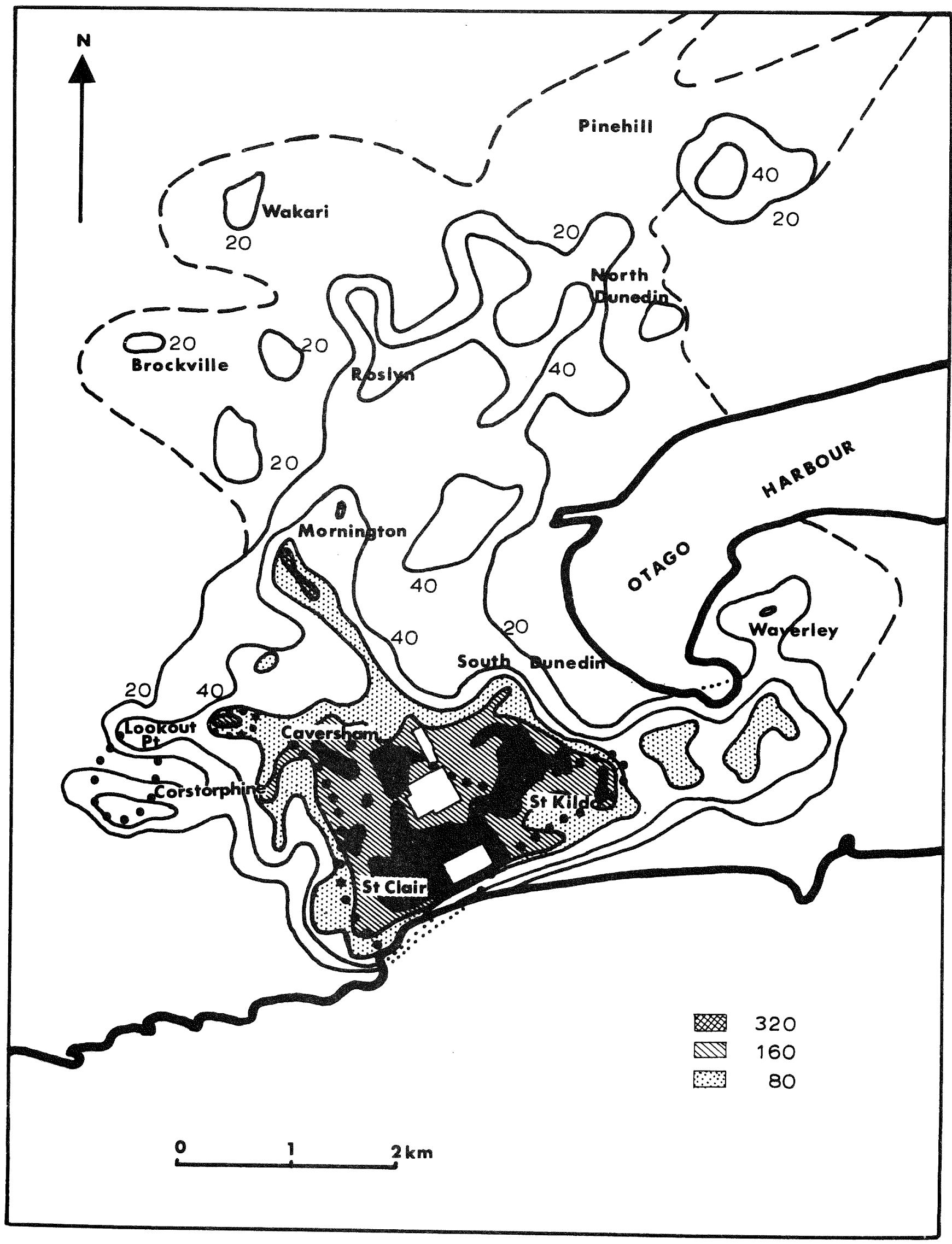

FIGURE 2: DENSITY OF DAMAGE CLAIMS RESUL TING FROM THE DUNEDIN EARTHQUAKE CONTOURS AT 20,40,80,160,320 CLAIMS PER km². DASHED LINE INDICATES LIMITS OF BUILT-UP AREA WHERE IT EXTENDS BEYOND THE LOWEST CONTOUR HEAVY DOTTED LINE INDICATES INNER ZONE OF MORE INTENSE CHIMNEY DAMAGE UNSHADED RECTANGULAR AREAS ARE LARGE PLAYING FIELDS 


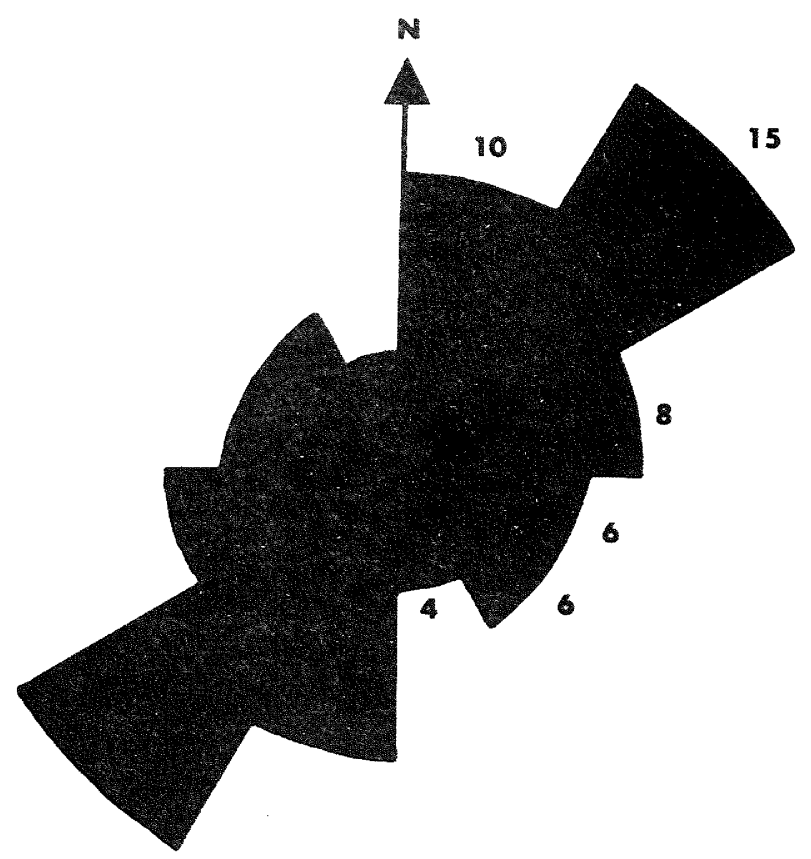

FIGURE 3: ROSE DIAGRAM OF FALL DIRECTIONS. GROUPED IN $30^{\circ}$ SECTORS. FROM 49 LOCALITIES. NUMBER OF OBSERVATIONS IN EACH SECTOR INDICATED.

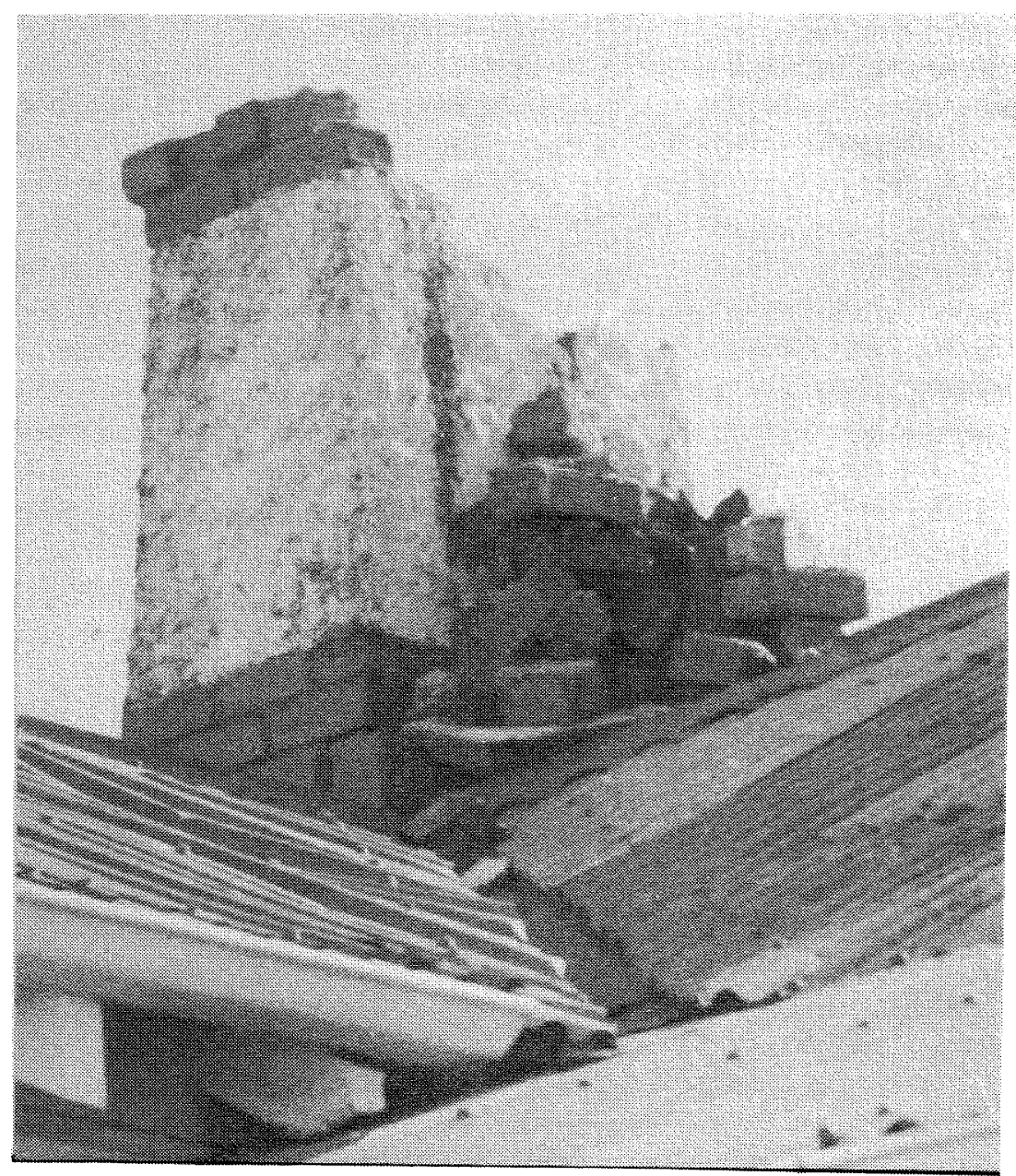

FIGURE 4: DAMAGED CHIMNEY ON HOUSE IN BAYVIEW ROAD. ST KILDA NOTE THE COMPLETE SEPARA TION OF THE COMPONENT BRICKS. PHOTOGRAPH LOOKING SOUTH-EAST. 


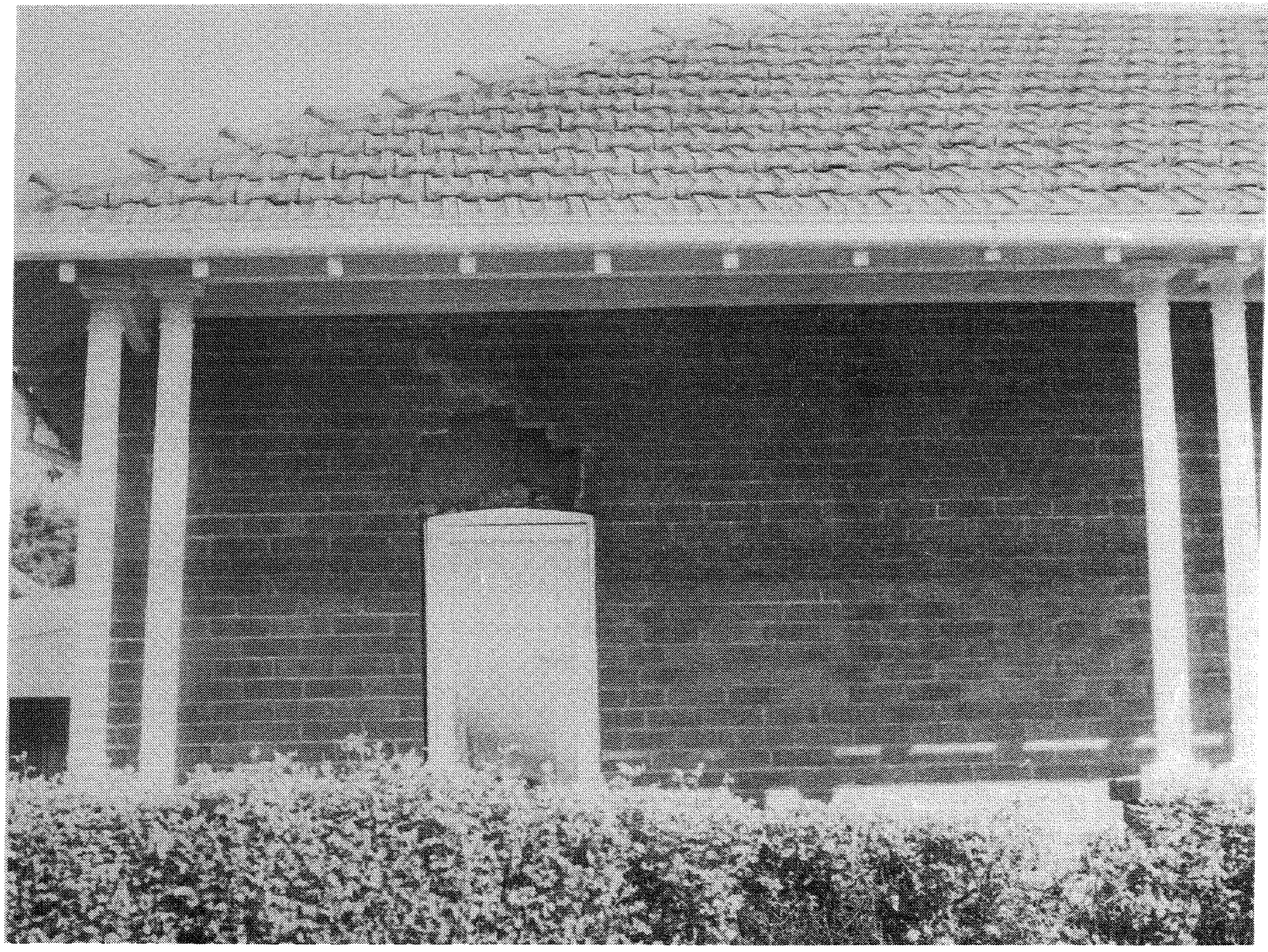

FIGURE 5: FAILURE OF BRICK VENEER AROUND WINDOW FRAME, JACKSON ST., ST KILDA. NOTE OPEN CRACK ON LEFT SIDE. PHOTOGRAPH LOOKING NORTH-WEST. 